\title{
Rearing Chrysomya megacephala on Artificial Diets Composed of Varying Concentrations of Albumin
}

\author{
Paloma Martins Mendonça ${ }^{1 *}$, Margareth Maria de Carvalho Queiroz ${ }^{1}$ and José Mario \\ d'Almeida ${ }^{1,2}$ \\ ${ }^{1}$ Laboratório de Transmissores de Leishmanioses; Setor de Entomologia Médica e Forense; Instituto Oswaldo \\ Cruz; Fundação Oswaldo Cruz; Av. Brasil, 4365; Manguinhos - RJ - Brasil. ${ }^{2}$ Departamento de Biologia Geral; \\ Universidade Federal Fluminense; Outeiro de São João Batista s/n; Niterói - RJ - Brasil
}

\begin{abstract}
Larvae of the blowfly Chrysomya megacephala were reared on an artificial diet composed of five different concentrations of albumin (2, 4, 6, 8 and 10\%) and the control group was fed on putrid bovine meat. No larvae developed in the 2 and 10\% albumin concentrations. The period from newly hatched larvae to adults reared on 4, 6 and $8 \%$ albumin was 13.1, 13.1 and 13.6 days, respectively, whereas for the control group, it was 11.2 days. Concentrations of 4, 6 and 8\% albumin proved viabile for larval periods of 29.3, 44.0 and 57.3\%, respectively, whereas for the control group, it was $77.3 \%$. Pupal viability was 77.3, 36.4 and $83.7 \%$, while for the control group, it was 84.5\%; the newly hatched larvae to adult viability was 21.3, 16.0 and $48.0 \%$, respectively, and for the control group, it was $65.3 \%$.
\end{abstract}

Key words: blowfly, Calliphoridae, development, Diptera, protein

\section{INTRODUCTION}

The blowfly Chrysomya megacephala (Fabricius, 1794) (Diptera: Calliphoridae) is abundant in the world's warmest regions and is important from the medical and sanitary standpoints. It was introduced into southern Brazil in the 1970s and today has been distributed widely throughout the Neotropical region (Guimarães et al., 1978; Prado and Guimarães, 1982). This fly is important because of its high natural population densities, high degrees of synanthopy and endophily, its potential to produce secondary myiasis in humans and other animals, and its use as a forensic indicator (James, 1947; Greenberg, 1971; Guimarães and Papavero, 1999; Oliveira-Costa and Mello-Patiu, 2004; Carvalho et al., 2004; Sukontason et al., 2005; Carvalho and Von Zuben, 2006).

Because C. megacephala feeds and breeds easily in human and animal feces, carrion, foodstuffs, liver and fish (Laurence, 1981; Baumgartner and Greenberg, 1984; d'Almeida, 1993), it is a potential mechanical vector of viruses, bacteria and other enteropathogenic organisms (Greenberg, 1971; 1973; Guimarães et al., 1979).

The natural diet used to rear $C$. megacephala is beef, but this meat putrefies in two or three days,

\footnotetext{
* Author for correspondence: palomamm@ioc.fiocruz.br
} 
when it begins to emit gases containing kairomone, which attracts other arthropods (Barbosa et al., 2004). Therefore, the discovery of new alternative diets that could reduce these problems as well as costs would lead to the insect's improved development and to higher breeding rates.

Various authors have tested artificial diets aimed at rearing calliphoridae in the laboratory (Leal et al., 1991; d'Almeida et al., 2000; Mendonça and d'Almeida, 2004; Barbosa et al., 2004).

The purpose of this study was to analyze the postembryonic development of C. megacephala reared on five different concentrations of albumin.

\section{MATERIALS AND METHODS}

\section{Insects}

Colonies of $C$. megacephala were started with flies collected on the Campus of the Oswaldo Cruz Foundation using a baited trap, as described by Ferreira (1978). The flies were kept in the laboratory, where they were fed on water and sugar, using bovine meat as the protein source.
Eggs obtained from the F2 generation were separated from the meat and kept on Petri dishes with a portion of the diet that would be tested.

After hatching, 30 larvae were transferred to a plastic container $(5 \mathrm{~cm} \times 7 \mathrm{~cm})$ with the corresponding diet. This container was placed inside a larger one $(10 \mathrm{~cm} \times 10 \mathrm{~cm})$ containing vermiculite and was covered with nylon netting. The experiments were maintained in climatized chambers set at $27 \pm 1^{\circ} \mathrm{C}$ and $70 \pm 10 \%$ RH. Daily observations were made and pupae were weighed $48 \mathrm{~h}$ after leaving the diet spontaneously. The adults' size was obtained by measuring the right middle tibia.

\section{Diets}

The diets were composed of albumin, vegetable oil, vitamins, mineral salt, agar, nipagin and distilled water. The experimental design consisted of five groups each with three replicates, and a control group fed on decomposed beef. Table 1 shows the composition of the diets.

The results were analyzed by ANOVA, the mean values compared by the Tukey-Kramer test and the sex ratio tested by $\chi^{2}$.

Table 1 - Proportion of ingredients in albumin diets.

\begin{tabular}{lccccc}
\hline \multirow{2}{*}{ Ingredients } & \multicolumn{5}{c}{ Protein $(\boldsymbol{\%})$} \\
\cline { 2 - 6 } & $\mathbf{2}$ & $\mathbf{4}$ & $\mathbf{6}$ & $\mathbf{8}$ & $\mathbf{1 0}$ \\
\hline Albumin $(\mathrm{g})$ & 2 & 4 & 6 & 8 & 10 \\
Vegetable oil (mL) & 0.21 & 0.21 & 0.21 & 0.21 & 0.21 \\
Vitamins and mineral salt (mL) & 2.21 & 2.21 & 2.21 & 2.21 & 2.21 \\
Agar (g) & 1.2 & 1.1 & 1.0 & 0.9 & 0.8 \\
Nipagin (g) & 0.3 & 0.3 & 0.3 & 0.3 & 0.3 \\
Distilled water (mL) & 94.08 & 92.18 & 90.28 & 88.38 & 86.48 \\
\hline
\end{tabular}

\section{RESULTS AND DISCUSSION}

Decomposed beef proved to be the best diet for rearing $C$. megacephala, which was understandable since Calliphoridae larvae developed in animal carcasses (Fig. 1). Leal et al. (1982) reported the same results for Chrysomya putoria (Wiedemann, 1818), on which they tested artificial diets and used mouse carcass to feed the control group. Bovine meat has been used by many authors as the preferential diet to rear muscoids dipteran (Oliveira et al., 2002).
There was no larval development in 2 and $10 \%$ albumin, possibly because of a lack of protein in the former concentration and excess of protein in the latter.

The various artificial diets tested did not lead to any significant differences in the duration of the larval period, but the duration differed considerably when compared with the control group (Fig. 1). The larval period was significantly longer with 4,6 and $8 \%$ albumin $(6.5,7.1$ and 6.6 days, respectively) than that of the control group (4.0 days). Tachibana and Numata (2001) reared 
Lucilia sericata (Meigen, 1826) on an artificial diet of whole powdered milk, dry yeast and wheat germ and found that the duration of the larval period on this artificial diet was slightly longer than on bovine liver. This could be attributed to the larvae's difficulty to extract the necessary amount of nutrients from these diets.
Albumin contains all the essential amino acids, including the ones that Diptera require for their development (Daad, 1977). According to Chippendale (1978), insect feeding could be retarded or even inhibited simply by a deficit or surplus of essential nutrients.

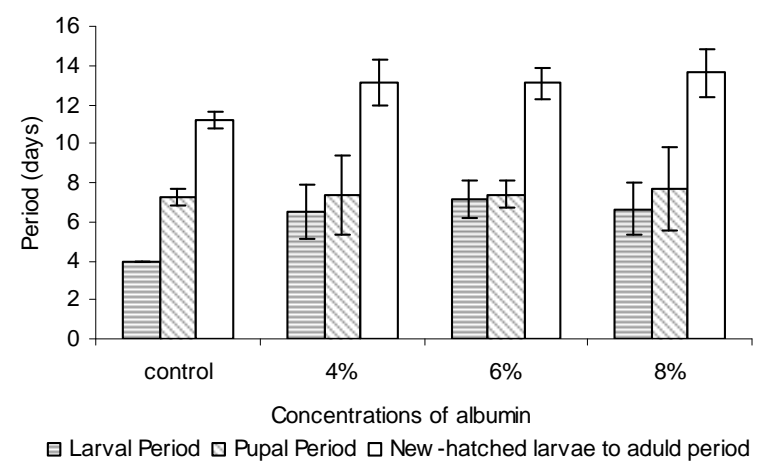

Figure 1 - Larval, pupal and newly hatched larvae to adult period, in days, of Chrysomya megacephala reared on artificial diets composed of various concentrations of albumin.

The pupal period lasted almost the same time with all the diets tested $(7.2,7.3,7.4,7.67$ days, respectively), i.e., 4,6 and $8 \%$ albumin and the control group, showing no significant difference between artificial and natural diets. Others authors reported the same findings after rearing $C$. megacephala with other artificial diets (Mendonça and d'Almeida, 2004; d'Almeida et al., 2000).

However, the control group showed a shorter period from newly hatched larvae to adult (11.2 days) than the flies reared on 4, 6 and $8 \%$ albumin (13.1, 13.1 and 13.6 days, respectively), and significant differences were also observed among these groups.

Laboratory observations have shown that when the larval period is very long, the pupal period tends to be shorter. According to d'Almeida et al. (2001), evaluating diets based on the parameter of the newly hatched larvae to adult period seems to be the most efficient method, since it sidesteps distortions between the larval and pupal periods.

Figure 2 illustrates the viabilities of larval, pupal and newly hatched larvae to adult period. Concentrations of 4 and $6 \%$ albumin showed the lowest viabilities of all the periods. An 8\% concentration of albumin showed a viability of $57.3 \%$ in the larval period, with a significant difference between this diet and all the others. In the pupal period, the viability of $8 \%$ albumin was almost the same as that of the control group, i.e., 83.7 and $84.5 \%$, respectively, and these diets produced results differing significantly from the others. All viabilities from the newly hatched larvae to adult period were low, including that of the control group (Fig. 2).

Control group pupae were the heaviest, while those bred with 6 and $8 \%$ albumin were the lightest, as indicated in Figure 3. Lopes (1941), reported that adults from heavy pupae were larger than those from lighter ones, which was confirmed in this study. The control group adults were the largest.

The sex ratio was homogeneous, varying from 0.4 to 0.6, which, according to Fisher (1930), indicated populational stability (Fig. 4).

According to d'Almeida and Lopes (1983), the rapid colonization process of calliphoridae was associated with the presence of humans. These flies are intrinsically linked to humans and to the garbage they produce, which serves as a food source for Diptera.

The artificial albumin diets proved unfavorable for rearing $C$. megacephala, but it should be emphasized that, in its natural habitat, this species was necrophagous and that this was the fly's first contact with artificial diets. 


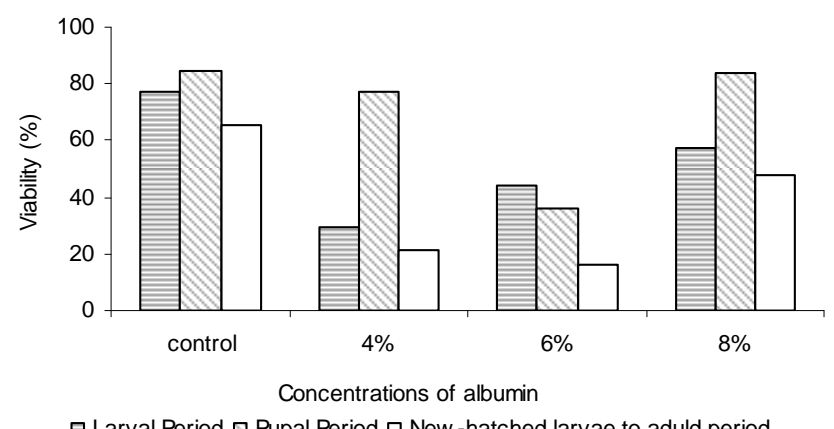

Figure 2 - Viability of larval, pupal and newly hatched larvae to adult period, in days, of Chrysomya megacephala reared on artificial diets composed of different concentrations of albumin.

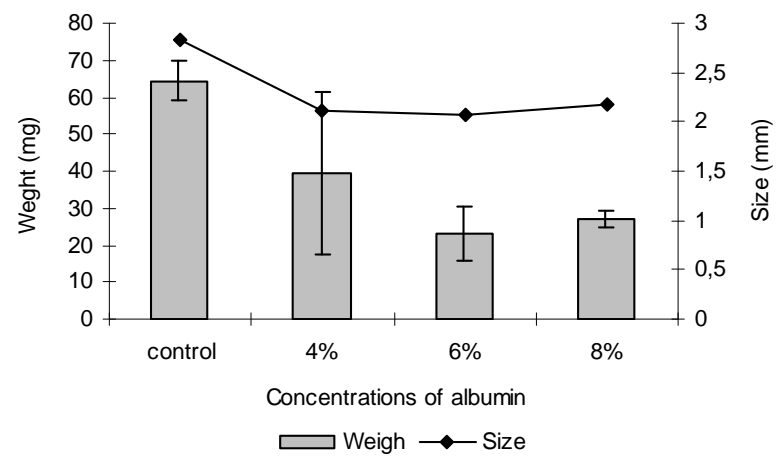

Figure 3 - Pupal weight and adult size of Chrysomya megacephala reared on artificial diets of various concentrations of albumin.

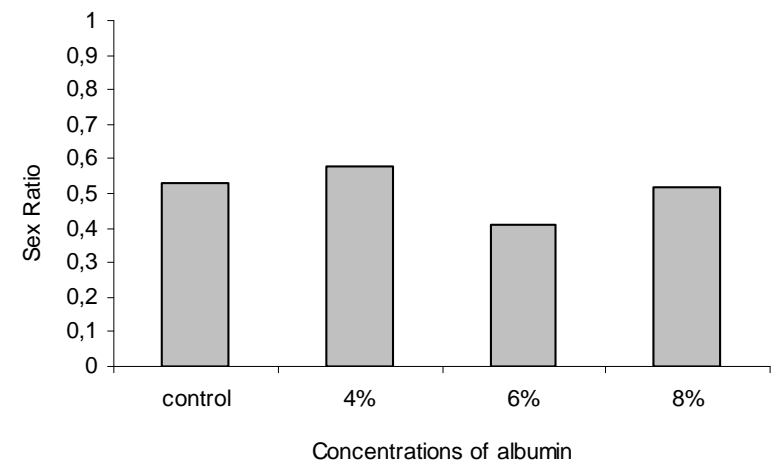

Figure 4 - Sex ratio of Chrysomya megacephala reared on artificial diets composed of albumin in varying concentrations. 


\section{AKNOWLEDGEMENT}

The authors wish to thank FAPERJ for its support of this work.

\section{RESUMO}

O presente trabalho teve como objetivo avaliar o desenvolvimento pós-embrionário de Chrysomya megacephala (Fabricius, 1794) (Diptera: Calliphoridae) em dietas artificiais à base de albumina nas concentrações de $2 \%, 4 \%, 6 \%, 8 \%$ e $10 \%$ de albumina e como controle foi utilizada a carne bovina moída putrefata. Não houve desenvolvimento nas dietas de concentração $2 \%$ e $10 \%$ de albumina. A duração do período de larva a adulto foi 13,1; 13,1 e 13,6 dias, respectivamente, e a do controle foi de 11,2 dias. As dietas artificiais nas concentrações 4, 6 e $8 \%$ de albumina apresentaram viabilidades larvais de 29,$3 ; 44,0$ e $57,3 \%$, respectivamente e o controle $77,3 \%$; as viabilidades de pupa foram 77,$3 ; 36,4 \mathrm{e}$ $83,7 \%$ e o controle $84,5 \%$, respectivamente; as viabilidades de larva a adulto foram 21,$3 ; 16,0$ e $48,0 \%$ e o controle foi de $65,3 \%$, respectivamente.

\section{REFERENCES}

Baumgartner, D. L. and Greenberg, B. (1984), The genus Chrysomya (Diptera: Calliphoridae) in the new world. Journal of Medical Entomology, 21, 105-113.

Barbosa, L. S.; Jesus, D. M. L. and Aguiar-Coelho, V. M. (2004), Longevidade e capacidade reprodutiva de casais agrupados de Chrysomya megacephala (Fabricius, 1794) (Diptera: Calliphoridae) oriundos de larvas criadas em dieta natural e oligolítica. Revista Brasileira de Zoociências, 6, 207-217.

Carvalho, L. M. L.; Thyssen, P. J.; Goff, M. L. and Linhares, A. X. (2004), Observations on the succession patterns of necrophagous insects on a pig carcass in a urban area of southeastern Brazil. Journal of Forensic and Medical Toxicology, 5, 3339.

Carvalho, M. H. and Von Zuben, C. J. (2006), Demographic Aspects of Chrysomya megacephala (Diptera, Calliphoridae) Adults Maintained under Experimental Conditions: Reproductive Rate Estimates. Brazilian Archives of Biology and Technology, 49, 457-461.

Chippendale, G. M. (1978), In - Técnicas de Criação de Insetos para Programas de Controle Biológico, ed. J. R. P. Parra. ESALQ, Piracicaba, São Paulo, SP, pp. 125.
d'Almeida, J. M. and Lopes, H. S. (1983), Sinantropia de dípteros muscóides (Calliphoridae) no Estado do Rio de Janeiro. Arquivos da Universidade Federal Rural do Rio de Janeiro, 6, 39-48.

d'Almeida, J. M. (1993), Capture of caliptrate flies with different breeding substrates on beaches in Rio de Janeiro, RJ, Brazil. Memórias do Instituto Oswaldo Cruz, 88, 215-220.

d'Almeida, J. M.; Fraga, M. B. and Ferro, C. L. (2000), Desenvolvimento pós-embrionário de Chrysomya megacephala (Diptera: Calliphoridae), em dietas artificiais. Entomologia y Vectores, 7, 155-162.

d'Almeida, J. M.; Ferro, C. L. and Fraga, M. B. (2001), Desenvolvimento pós-embrionário de Chrysomya putoria (Diptera: Calliphoridae) em dietas artificiais. Acta Biologica Leopondensia, 23, 25-30.

Dadd, R. H. (1977), Qualitative requirements and utilization of nutrients: insects. In - Handbook Series in Nutrition and Food, ed. M. Rechcigl. C.R.C. Press, Cleveland, pp. 305-346.

Ferreira, M. J. M. (1978), Sinantropia de dípteros muscóides de Curitiba, Paraná. I. Calliphoridae. Revista Brasileira de Biologia, 38, 445-454.

Fisher, R. A. (1930), In - Biologia Evolutiva, ed. D. J. Futuyma. Sociedade Brasileira de Genética, Ribeirão Preto, SP, pp. 631.

Greenberg, B. (1971), Flies and Diseases. Vol. I: Ecology, Classification and Biotic Associations. Princeton, New Jersey. 861p.

Greenberg, B. (1973), Flies and Diseases. Vol. II: Biology and Diseases Transmission. Princeton, New Jersey. 845p.

Guimarães, J. H.; Prado, A. P. and Linhares, A. X. (1978), Three newly introduced blowfly species in Southern Brazil (Diptera: Calliphoridae). Revista Brasileira de Entomologia, 22, 53-60.

Guimarães, J. H.; Prado, A. P. and Buralli, G. M. (1979), Dispersal and distribuition of three newly introduced species of Chrysomya R.D. (Diptera: Calliphoridae) in Brazil. Revista Brasileira de Entomologia, 23, 245-255.

Guimarães, J. H. and Papavero, N. (1999), Myiasis in man and animals in the neotropical region. Plêiade, Brasil. 308p.

James, M. T. (1947), The flies that cause myiasis in man. United States Department of Agriculture, 631, 175.

Laurence, B.R. (1981), Geographical expansion range of Chrysomya blowflies. Transactions of the Royal Society of Tropical Medicine and Hygiene, 75, 13031.

Leal, T. T. S.; Prado, A. P. and Antunes, J. A. (1982), Rearing the larvae of the blowfly Chrysomya chlopyga (Wiedemann) (Diptera: Calliphoridae) on oligidic diets. Revista Brasileira de Zoologia, 1, 4144.

Leal, T. T. S.; Antunes, J. A. and Prado, A. P. (1991), Growth of Chrysomya putoria blowfly larvae in 
relation to dietary casein concentration. Medical and Veterinary Entomology, 5, 139-141

Lopes, H. S. (1941), Sobre o aparelho genital dos Sarcophagidae (Diptera) e a sua importância na classificação. Revista Brasileira de Biologia, 1, 215221.

Mendonça, P. M. and d'Almeida, J. M. (2004), Desenvolvimento pós-embrionário de Chrysomya megacephala (Fabricius, 1794) (Diptera: Calliphoridae) em dietas artificiais à base de leite. Entomologia y Vectores, 11, 50-67.

Oliveira, V. C.; Mello, R. P. and Santos, R. F. S. (2002), Bionomic Aspect of Pattonella intermutans (Thomson, 1869) (Diptera, Sarcophagidae) under laboratory conditions. Brazilian Archives of Biology and Technology, 45, 473-477.

Oliveira-Costa, J. and Mello-Patiu, C. A. (2004), Application of forensic entomology to estimate of the postmortem interval (PMI) in homicide investigations by the Rio de Janeiro Police Department in Brazil. Journal of Forensic Medicine and Toxicology, 5, 40-44.
Prado, A. P. and Guimarães, J. H. (1982). Estado atual de dispersão e distribuição do gênero Chrysomya Robineau-Desvoidy na região Neotropical (Diptera: Calliphoridae). Revista Brasileira de Entomologia, 26, 225-231.

Sukontason, K. L.; Narongchal, P.; Sripakdee, D.; Boonchu, N.; Chaiwong, T.; Ngern-Klun, R.; Piangjai, S. and Sukontason, K. (2005), First report of human myiasis caused by Chrysomya megacephala and Chrysomya rufifacies (Diptera: Calliphoridae) in Thailand, and its implication in forensic entomology. Journal of Medical Entomology, 42, 702-704.

Tachibana, S. and Numata, H. (2001), An artificial diet for blow fly larvae, Lucilia sericata (Meigen) (Diptera: Calliphoridae). Applied Entomology and Zoology, 36, 521-253.
Received: November 20, 2006; Revised: April 30, 2007; Accepted: June 27, 2008. 